Athens Journal of Business \& Economics -

Volume 8, Issue 1, January 2022 -Pages 21-42

\title{
Attitudes of the Indian Middle Class: A Theory of Planned Behavior Approach
}

\author{
By Somjit Barat ${ }^{*}$
}

\begin{abstract}
The author conducts a pilot study to investigate whether the benefits of global marketing and the purported liberal policies of the Government of India have percolated to the Indian middle-class since the year 2014, when the present government came to power. The author collects data through online surveys from Indian citizens, and then conducts a qualitative analysis of the same to test six propositions based on Maslow's Hierarchy of Needs Model and the Theory of Reasoned Action. The author finds moderate to strong support for five of his propositions and sets the stage for a more robust research study that the author is planning to conduct on this highly relevant topic.
\end{abstract}

Keywords: globalization, consumer experience, marketing strategy, political marketing

\section{Introduction}

\section{Summary Statement of Contribution}

To the best of the author's knowledge, there does not exist any study in the marketing domain that attempts to validate the Indian government's claim to fame by polling Indian citizens. Thus, in addition to filling a void in extant literature, our research can help the government align its prerogatives to better serve the citizens and utilize its scarce resources more effectively and efficiently. Overall, the government can utilize the results to reorient its political marketing strategy. Concurrently, international bodies such as the World Bank or IMF can utilize the findings to recalibrate their measuring instruments so as to reflect a more accurate socio-political picture of comparable countries.

\section{Background and Motivation}

The Indian Government claims that its futuristic policies have yielded rich dividends by reducing red tape, improving civil laws and regulations leading to quicker decisions at the bureaucratic level, improving literacy, healthcare and education. Over the last decade, substantial changes have taken place at both the policy/planning as well as the execution levels; while power has been held by different political parties, new policies and practices have replaced older ones. Today, India is considered amongst the most formidable economies in the world not just in terms of size, but also in terms of gross domestic product growth rates that are historically among the highest, currently pegged at $5 \%$ in the first quarter

*Associate Professor, School of Business, Pennsylvania State University, USA. 
of 2019 (The Economic Times 2019) compared to US's 2.1\% growth rate during the same time period (Amadeo 2019).

Not unexpectedly, the current government claims that such growth resulted from its robust policies and their deft execution. Specifically, the government touts its long-term globalization plans as people-oriented, and responsible for fasttracking the country's progress (AlEnezi et al. 2018). The current government also claims that in contrast to the actions of previous political parties in power since India's independence in 1947, it has introduced a strong culture of accountability and transparency in terms of how it operates (Blair 2018, Basu 2016, Mookherjee 2014, Rose-Ackerman and Palifka 2016). Another major claim by the present government is that it has reduced economic disparity by aggressively identifying, pursuing and eventually prosecuting individuals responsible for corruption and money-laundering (Yap 2017, Passas 2015, Kumar 2015).

Many of the standard indicators of progress appear to support the government's claims, such as growth rate of gross domestic product (GDP), banking infrastructure, availability of credit and ease of securing loans both by private citizens and by businesses etc. (For specifics on individual parameters, the reader may visit https://rbi.org.in/Scripts/AnnualPublications.aspx ?head=Handbo ok\%20of\%20Statistics\%20on\%20Indian\%20Economy).

Nonetheless, the common person's opinions about the future of the country have taken a hit in recent times (The Economic Times 2018), especially in light of their experiences with the "Aadhar" scheme (biometric identification), and demonetization measures introduced by the government (Chaudhuri and Konig 2017, Mali 2016, Singh and Singh 2016, Shirley 2017, Srinivasan et al. 2018, Nair 2017).

Consider, for example, the government's demonetization measure adopted in November 2016 in which, all 500- and 1000-rupee bills were declared null and void by the government overnight. The Government's goal for this drastic step was to eradicate black money, illegal transactions, counterfeit notes and funding of terrorist activities from across the border.

For a country of 1.2 billion people and where more than $80 \%$ of daily transactions are conducted in cash, such sudden move by the Government created considerable inconvenience for the common citizen, as well as for small businesses. Common citizens stood in lines for hours trying to withdraw cash at banks, post offices and ATM-s (Mali 2016). Jewelry stores, gas stations, merchandise vendors and other such small businesses, whose survival depends on daily cash flows, were scrambling to either sell off their wares or exchange their now-defunct 500- or 1000-rupee bills. Thus, notwithstanding the Government's prescribed goals, the true effect of the demonetization step is subject to investigation.

According to a Consumer Confidence Survey conducted by the Reserve Bank of India (India's central bank), the mood on the current state of the economy has shown marginal improvement, even though it is still in negative territory. Future expectations index, on the other hand, have shown marginal decline during the 2017-2018 time-period. More specifically, the current expectation about the economic situation and employment prospects appear to have improved compared 
to a year earlier, even though the numbers are in negative territory. Perceptions about price level, however, seem to have gotten worse. Income expectation (which was in positive territory originally) in the current year has gone down marginally compared to a year ago. Spending, which also enjoyed a positive index a year ago, has marginally improved. Overall, the negative sentiment of consumers has improved from what it was a year ago (Table 1).

Citizens' future expectations one year ahead, however, paint a different picture. For example, economic situation, income, and price level all suffered declines among the respondents, which led to a marginal decline in consumer confidence index from 118.4 to 117.8 points. Spending and employment exhibit upward trend whereas economic outlook and spending exhibit a downward trend. Price level, which was originally in the red territory, showed further deterioration when respondents were asked to project their expectation one year ahead.

Table 1. Summary Results of Indian Consumer Confidence

\begin{tabular}{|c|c|c|c|c|c|c|}
\hline \multicolumn{7}{|c|}{ Summary based on Net Response } \\
\hline \multirow[t]{2}{*}{ Main Variables } & \multicolumn{3}{|c|}{$\begin{array}{l}\text { Current Perception } \\
\text { compared with one-year ago }\end{array}$} & \multicolumn{3}{|c|}{$\begin{array}{c}\text { One year ahead Expectations } \\
\text { compared with current } \\
\text { situation }\end{array}$} \\
\hline & May-18 & Jun-18 & Change & May-18 & Jun-18 & Change \\
\hline Economic Situation & -16.1 & -7.4 & & 21.7 & 20.5 & \\
\hline Income & 3.3 & 2.6 & & 40.6 & 38.4 & \\
\hline Spending & 81.0 & 81.9 & & 82.4 & 84.0 & \\
\hline Employment & -12.6 & -6.5 & & 24.5 & 24.6 & \\
\hline Price Level & -85.0 & -85.8 & & -77.3 & -78.3 & \\
\hline $\begin{array}{l}\text { Consumer } \\
\text { Confidence Index }\end{array}$ & 94.1 & 96.9 & & 118.4 & 117.8 & \\
\hline \multicolumn{3}{|c|}{$\begin{array}{c}\text { Positive Sentiments with sign of } \\
\text { improvement compared to last round }\end{array}$} & \multicolumn{4}{|c|}{$\begin{array}{l}\text { Negative Sentiments with sign of } \\
\text { improvement compared to last round }\end{array}$} \\
\hline \multicolumn{3}{|c|}{$\begin{array}{l}\text { Positive Sentiments with sign of } \\
\text { deterioration compared to last round }\end{array}$} & \multicolumn{4}{|c|}{$\begin{array}{l}\text { Negative Sentiments with sign of } \\
\text { deterioration compared to last round }\end{array}$} \\
\hline
\end{tabular}

Source: Adapted from Reserve Bank of India 2019.

Given that the citizen sentiment conflicts with that of the current government, the author concludes that there is considerable evidence to warrant further investigation as to how reliable the current government's claims are, which provides the motivation for the current proposal. It may be noted that for the purpose of this research, individuals earning 20,000 rupees or less per month are considered at the lower spectrum of the middle-income population; those earning in the range of 20,001-40,000 rupees per month are considered the middle spectrum, whereas those earning 40,001-60,000 rupees per month are considered to be in the upper range of the middle-income population (Birdsall 2010, Javalgi and Grossman 2016, Kharas 2017, World Bank 2012) and also as recognized by World Bank standards (https://blogs.worldbank.org/opendata/new-country-classi 
fications-income-level-2017-2018). At the current exchange rate (1 USD=71.62 rupees), the above income brackets translate to $\$ 279, \$ 280-\$ 358$ and $\$ 359-\$ 837$ per month. The next few sections describe India's ascension to superpower status and how the Indian middle class played a critical role in helping India achieve the same.

\section{India's Rise to Power}

India, like China, Brazil, Russia or South Africa (BRICS conglomerate) has been on the cusp of breaking free from the shackles of poverty for almost two decades. Moreover, unlike the other countries, India has had a very strong democracy and stable governance since independence, not to mention friendly relations with other countries (Wilkinson 2015, Sharma 2016a, Suri et al. 2016, Bernstein 2014), with its respective caveats.

What has made India's case unique is its ability to hold on to and nurture its traditions, religious beliefs and roots, even as it imbibed modern culture, practices, customs and technology. Overall, even though different political parties have lost and gained power over the last two decades, the importance and long-term goal of embracing liberalization using global marketing was never lost to any of the ruling parties.

Consequently, the seeds of change sown by the Congress government in the 1990-s set India on a path to development from which the country never really looked back. More importantly, Indians began to believe in themselves, and in their ability to come out from the shackles of poverty. The lower and middle class became energized and took it upon themselves to toil their way to achieving higher standards of living, just like the West (Galanter 2015, Donner 2016, Javalgi and Grossman 2016, Ahmad and Reifeld 2017, Sinha et al. 2017) several decades earlier.

Such positive developments have made India the "poster child" of liberalization and global marketing, where it has leveraged its strengths in numbers to overcome its weaknesses in infrastructure, enhancing of transparency in government actions (Sharma 2015) and has converted its threats from neighboring countries to create opportunities with like-minded partner countries. Concurrently, India appears to struggle with a different kind of problem: how to sustain its phenomenal growth rate and how to feed the growing aspirations of its citizens, especially the burgeoning middle class (World Bank 2012). While a high growth rate is a "good" problem to have, recently the country has witnessed some unexpected fluctuations (Naser 2015, Banerjee and Roy 2014). This, however, can turn into a serious concern if the ruling government is unable to fulfill its promises of "Acche Din" i.e., good days, as promised by the current Prime Minister-and, in the process, belie the high expectations of its citizens.

The debate has assumed more prominence in the light of certain draconian and drastic steps that the government has initiated i.e., demonetization (Rama 2018, Soni and Soni 2017, Chanda 2016), and the goods and services tax or GST (Kumar 2014, Basak 2017, Raj 2017, Khurana and Sharma 2016). 
The author, therefore, believes that conducting such research, which involves analyzing both primary and secondary data, will give the reader a more holistic picture of how realistic the present government's claims are. It can also potentially bring to the fore how effective the current government's marketing strategy is, both to its "internal stakeholders" (i.e., Indian people) and to its "external stakeholders" (i.e., international organizations such as World Bank, IMF, UN and trading partners). The next section describes how the Indian middle class is relevant and extremely important in the context of the current study.

\section{Indian Middle Class}

The relevance of the Indian "middle class" in the current research context cannot be overemphasized. As per latest census data available, in 2011-2012, close to 600 million people (about $50 \%$ of the population) belonged to the middle class.

Not only is 600 million a number to reckon with, but it exceeds the entire population of Europe as of January 1,2017 (512 million, according to Eurostat, 2017). As in many other countries (both similar to and different from India in terms of its size and structure), the middle class is the largest and most significant in terms of its contribution to the economy. What is even more important in the Indian scenario is that, its middle class has almost doubled in number between 2005-2006 and 2010-2011. Thus, there is no reason to doubt the considerable power that this social class yields in India.

The purchasing power of the middle class has increased exponentially, and continues to do so, making this segment of the population the most sought-after by both national and foreign governments. In 2015 for example, Indian middle-class consumption was about \$1.9 trillion (in 2011 constant purchasing power parity or PPP) and accounted for about $5 \%$ of the global share. The subsequent numbers for 2020 and 2030 are predicted to be $\$ 3.7$ trillion and $9 \%$ and $\$ 10.7$ trillion and $17 \%$ respectively (Kharas 2017), all of which clearly indicate that the Indian middle class is a force to reckon with (Krishnan and Hatekar 2017). In other words, the current research makes valuable contribution both from economic as well as political marketing and planning perspectives. In the next section, we introduce the theoretical framework and present our propositions for research.

\section{Relevance to Marketing}

The present Indian government's claim to fame is that it listens to and understands the major challenges that the citizens face on a daily basis. It wants to debunk the common perception that government machinery is slow, corrupt and opaque in its operations. As such, the results of the research will prove insight into whether the government has been able to create, communicate and deliver value for its "customers" i.e., the Indian citizens (to borrow from the American Marketing Association's definition of "marketing" 2018).

Secondly, there is considerable research on the association between a country's level of global marketing (outreach efforts by a national government to 
the international community) and rise in income (Kleinert 2018, Solomon et al. 2014, Dabla-Norris et al. 2015), and financial condition (Broner and Ventura 2016, Post and Byron 2015, Yeung and Coe 2015). Other researchers have shown how global marketing influences economic growth and developmental index in developing countries (Kilic 2015, Malhotra et al. 2018, Kowalski et al. 2015), corruption and citizens' perception of the government (Asongu 2014). There also exists considerable research on the impact of global marketing on the citizens' consumption behavior (Anderson and He 2015, Bartsch et al. 2016, Bhattacharya et al. 2016). Thus, there is hardly any doubt that global marketing affects the people of the country as well as international developmental indicators. In addition, the standing of the country in the international community and its ability to negotiate favorable terms of loans and trade benefits are direct effects of India's global marketing ability, which appears to play a big role in portraying India as one of the most potent countries in the world.

This research is also interesting and relevant from an environmental scanning perspective. There exists considerable research on how India has exhibited remarkable progress and achieved international exposure and status within a short period after the present government came to power (Coale and Hoover 2015, Shahbaz et al. 2016, Rakodi 2014, Shahbaz et al. 2017, Beckett and Taylor 2016). India's credit rating, developmental index, standard of living index, ease of doing business index, corruption index, loan default index, crime statistics, happiness index, ability to attract foreign investment etc. have experienced marginal to significant improvements under the current regime.

Such recognition by the international community is possible only when the government has carried out "due diligence" in the form of the traditional SWOT (strengths, weaknesses, opportunities, threats) analysis. Specifically, in the case of India, historically, the government realizes that the country's strengths lie in the availability of a large pool of educated, English-speaking youth, focus on attaining college degree in the hard sciences, ready access to human capital, and an insatiable hunger of other countries to outsource their services to Indian companies (Kaushal and Pathak 2015, Shetty 2017, Sharma 2016b). Simultaneously, the government realizes that it needs to improve in the areas of population increase, basic infrastructure, and corruption (Chakrabarti et al. 2015, Ganguli 2016, Sharma 2016b, Mukherji 2016). India's economic and strategic threats arise from other countries in the BRICS conglomerate as wells as China, Vietnam, and Korea. In terms of opportunities, India continues to exhibit a lot of potential in handicrafts exports, space technology and human capital (Kavalski 2016, Burgess 2015, Thayer 2014, Envall and Hall 2016, Seth 2016). Consequently, India has had to juggle its strategic partnerships with countries all over the globe, both big and small. Therefore, the author's research will also reveal the efficacy of the current government's marketing tool in terms of improving India's image in the international arena. 


\section{Conceptual Framework and Proposition Development}

The current research is anchored to two theoretical frameworks: Theory of Reasoned Action and Maslow's Hierarchy of Needs Model. The following two sections will be devoted to a brief description of these two streams of research, supported by a brief review of relevant literature, which the author will utilize to dovetail into the research propositions.

\section{Theory of Reasoned Action}

The Theory of Reasoned Action (TRA) provides an appropriate framework within which the current research can be anchored. According to this framework, the individual's beliefs about the outcomes or consequences of his/her action influences the individual's attitude towards such actions. The individual's attitude, in turn, influences his/her intention to actually conduct such behavior (Fishbein et al. 1980, Fishbein and Ajzen 1975, Fishbein and Jaccard 1973). Ajzen subsequently revised the TRA to present the Theory of Planned Behavior (TPB). Ajzen emphasizes that in general, human beings are "rational", and not fickle-minded. Once they set a goal/intend to achieve an outcome, it can be predicted with reasonable certainty that they will take action to achieve that goal. To quote Ajzen (1985), "Before attending a concert, for example, a person may extend an invitation to a date, purchase tickets, change into proper attire, call a cab, collect the date, and proceed to the concert hall. Most, if not all, of these activities will have been designed in advance; their execution occurs as the plan unfolds. To be sure, a certain sequence of actions can become so habitual or routine that it is performed almost automatically, as in the case of driving from home to work or playing the piano. Highly developed skills of this kind typically no longer require conscious formulation of a behavioral plan".

Thus, if an individual believes that the government has drafted and implemented policies that have enhanced their standard of living, they will have a favorable attitude towards the government and vice versa. Consequently, such attitude will be reflected in their intention to participate in certain behaviors such as spend more (or less) on consumer goods, borrow more (or less) to buy big ticket items, invest more (or less) in education, health, real estate, and consume more (or less) self-esteem activities such as enrolling in prestigious societies, attending concerts and participate in more (or less) self-actualization activities such as charity work, and donations. Given that an individual's intention is a robust indicator of actual behavior as per the TPB, the author measures the respondent's intention rather than actual behavior in a survey. In other words, the respondents' perceptions about purchase behavior, prices, health care, education opportunities and living standards constitute the independent variables, whereas the perception/ attitude towards the present Indian government's claims is the dependent variable for the current research model (Figure 1). 
Figure 1. The Theory of Reasoned Action as Applied to Consumer Behavior

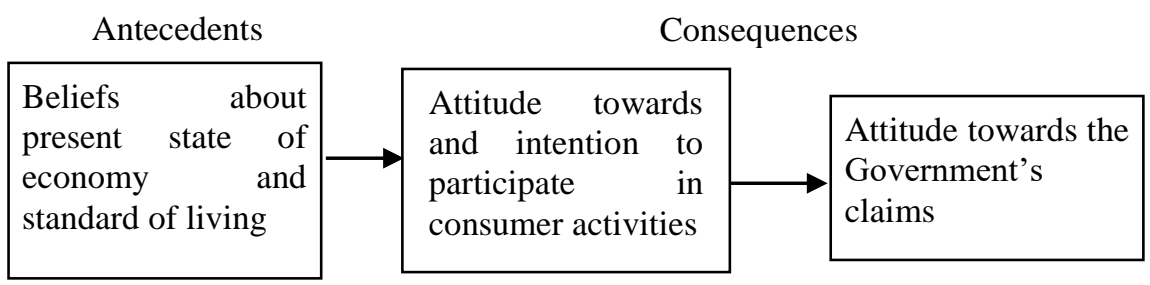

Source: Adapted from Fishbein et al. (1980, p. 8).

\section{Maslow's Hierarchy of Needs}

The author bases his proposed research on Maslow's Pyramid of social needs, which suggests that individuals' priorities shift in favor of higher-level needs only after more mundane needs have been satisfied. In other words, only when an individual's basic necessities like food, water, shelter and other physiological needs have been met, will they strive for (higher) safety needs (such as healthcare, insurance, protection from harm). As McLeod (2007) argues, Maslow believed that every individual has the capability and the desire to achieve more in life. However, human beings typically need to accomplish and feel content with the 'lower' level needs before they set their sights on the "higher" level traits such as love, self-esteem, self-actualization and so on. Sometimes, however, an individual might attempt to skip an intermediate step to strive for higher and greener pastures due to sudden and unexpected life events such as getting a new, higher-paying job, birth or loss of a loved one, marriage or divorce, winning a lottery or an unexpected major property loss due to fire or flood. Maslow's original model (Maslow 1943, 1954) as depicted in Figure 2, has been extensively used in social sciences research and modified/extended later (Maslow 1987, 2013). Given the significant transformation that Maslow's hierarchy has gone through in the last few decades, the author reviews the different stages of the hierarchy

Figure 2. Maslow's Hierarchy of Needs

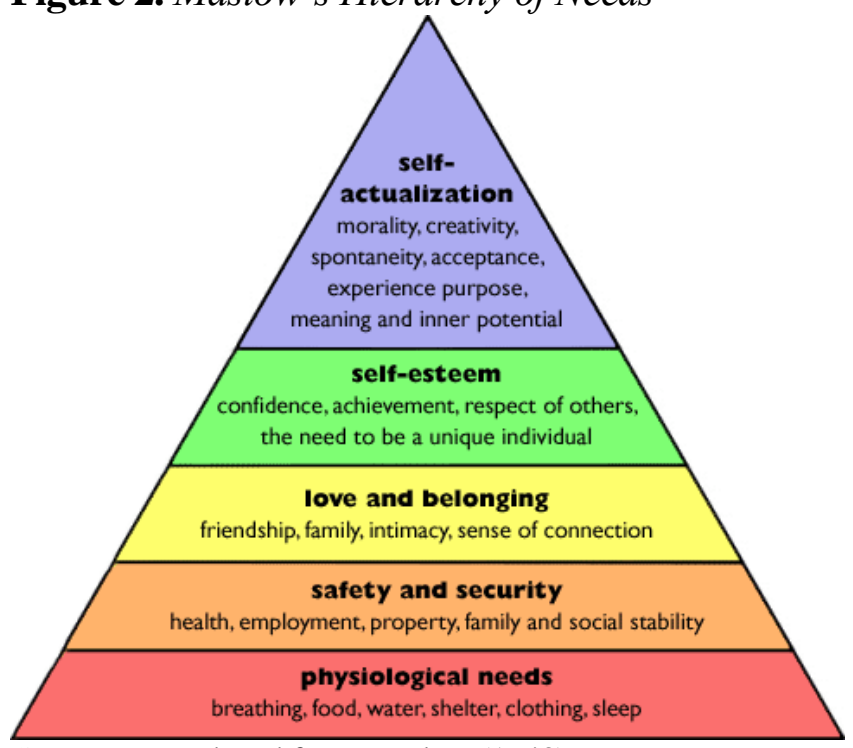

Source: Reproduced from Maslow (1943). 
Physiological Needs

Maslow suggested that physiological needs (such as food and sex) are critical for the very existence of the human body. Lack or want of food can lead to "hunger" or "appetite". In the poorest of poor circumstances, people suffer from hunger. This is different from a situation when a person suffers from appetite i.e., the person is not necessarily starving but would rather have something to eat.

In India, starvation is a malignant issue. For example, in 2012, about $18 \%$ of India's population was undernourished, which amounted to almost 218 million people, and higher than the mal-nourishment rate of most countries (Mitra 2015). While average recommended calorie intake is 2,000 for women and 2,500 for men (Gunnars 2018), the poorest of the Indian adult population can afford no more than $60 \%$ of the recommended calories. In other words, a considerable percentage of the population is still struggling with access to physiological needs, which motivates the first proposition for this research:

P1: The lower-middle income level population who may not have access to physiological needs may exhibit negative attitude towards the government's claims

\section{$\underline{\text { Safety Needs }}$}

Maslow's characterization is based on safety and security from external dangers like road accidents, attacks by miscreants, and physical safety from diseases, attack from animals, bug bites etc. It is for this reason that people often drive bigger cars, buy organic foods, live in gated communities, undergo preventative health check-ups and vaccines, or purchase health and life insurance. Arguably, it is only the middle-income segment of the population (who has fulfilled their physiological needs,) that turns their attention to higher (safety) needs. Consequently, if the government's claims are true, they might be more inclined to bear a positive disposition towards the government's claims, which motivates the second proposition as:

P2: Population at the middle-income level who perceive that they have access to better and more resources than before, may have a positive attitude towards the government's claims

\section{Love and Belonging Needs}

Once a person has adequate amount of bread on the table and protection from external threats, he/she wants to build a family, stay close to acquaintances, to be loved and cared for and reciprocate the same, empathize and have feelings towards close ones (Sheth et al. 1999, p. 347). While physiological needs are required for an individual to live, what Maslow referred to as "love and belonging" offers an individual a reason to live, which can be compared to an improvement in the person's standard of living. Hence, our next proposition is:

P3: Population that perceives an improved standard of living compared to the past may exhibit a positive attitude towards the government's claims 


\section{$\underline{\text { Self-Esteem Needs }}$}

The next higher-level need in Maslow's hierarchy can be attributed to two sources: internal and external. While internal self-esteem can come from achievement, recognition, self-indulgence or rewarding oneself with affordable luxuries, external self-esteem can be attributed to attention from others, professional achievements, membership and acquaintances in prestigious societies and the like (Datta 2014). Such status can typically be achieved by middle to higher-middle income population. In either case, such a feeling of esteem can be enhanced through earning a higher salary and consequent access to and purchase of luxury consumer goods (hi-tech gadgets, smart fridge, multifunctional cooking range), which motivates the following proposition:

\section{P4: Population that now has access to more luxury goods than before and hence higher self-esteem, may exhibit a positive attitude towards the government's claims}

Globalization, government encouragement to prop up the production infrastructure of the country, dramatic increase in bank loans and use of credit cards by the average person, have resulted in possession of more disposable income for the middle and higher-income Indian population of India. But such changes in economic outlook and access to resources can also be a double-edged sword, for the simple reason that people may experience a feeling of inadequacy. In other words, individuals who have acquired more money will realize that certain luxury items that were beyond their reach before, are still unaffordable. For some, this can lead to resentment and a feeling that the Government has not done enough for the hard-working people. For others, this can result in a perception that they are not rewarded appropriately for their hard work or, that the cost of living is too high. Consequently, Maslow's self-esteem needs also motivate the following proposition:

P5: Population at the lower middle-income level may be worse off compared to high-middle income people, and hence, may exhibit a negative attitude towards the government's claims

Self-actualization Needs: Maslow notes: "what a man can be must be. They must be true to their own nature....Musicians must make music, artists must paint, poets must write..." (Maslow 1987, chap. 2). In other words, every person must be given the option and opportunity to realize their potential. Arguably, individuals can reach their potential only when they have been able to satisfy their basic needs of food and shelter, built a safety net for themselves/family, accomplished the fruits of hard work by improving their standard of living and achieved selfsatisfaction and recognition from others. Self-actualization is a stage in the lifecycle of an individual where the person begins to think about his/her larger role in life: contribute to society, create a difference in others' lives and how he/she can make a "mark" on this earth. Typically, only one percent of the population (who control 99 percent of the aggregate wealth of the world) is privy to this ultimate 
stage of Maslow's hierarchy (De Neve and Powdthavee 2016, Martin 2015, Wolfers 2105). Individuals at this stage of Maslow's hierarchy are content with their accomplishments and current state in life. Naturally, they are likely to harbor a positive disposition towards the present government, which prompts the final proposition:

P6: Population at the top of the economic ladder may exhibit a positive attitude towards the government's claims

The following sections describe the methodology of the study, analyze the results, and validate the propositions presented by the author.

\section{Methodology}

\section{Instrument}

In order to collect primary data from Indian respondents, an instrument was designed consisting detailed queries on consumer's perceptions and actions about product purchase behavior, (see attached sample), health care, education opportunities and living standards, as well as items about the individual's trust in the present government. This instrument is loosely based on the Reserve Bank of India's Consumer Confidence Survey (2019). Needless to mention, the survey instrument underwent rigorous levels of scrutiny, several draft versions, and was reviewed thoroughly by experts in the fields of qualitative research and marketing.

The author collected data online from subjects representing the different professions such as government bureaucrats, physicians, students, retired people, and different demographics such as genders, age groups, income and education levels etc. This minimized any potential source of bias in responses.

\section{Results}

\section{Descriptive Statistics (Table 1)}

Respondents were marginally male-dominated (fifty-three percent), whereas their age-group was slightly skewed towards under-40 years (forty-three percent). An overwhelming majority of respondents were married (eighty percent), whereas their household size was more or less evenly distributed (two, three, four or more than four). In terms of monthly income, forty-three percent of respondents made more than sixty-thousand rupees. Sixty-one percent of respondents were employed, and thirty percent were retired or homemakers. Finally, an overwhelming majority of respondents owned their homes (eighty-three percent). These numbers are not significantly different from the overall Indian population (see Kharas 2017). As such, we can conclude that the data is representative of the general population and does not pose any concern for bias in the findings. 
As indicated earlier, respondents earning 20,000 rupees or less are considered at the lower spectrum of the middle-income population; those earning in the range of 20,001-40,000 rupees are considered the middle spectrum, whereas those earning 40,001-60,000 rupees are considered to be in the upper range of the middle-income population (Birdsall 2010, Javalgi and Grossman 2016, Kharas, 2017, World Bank 2012).

About sixty-five percent of the respondents in this income category thought that they were either the "same" or "worse off" in response to the following questions: "Compared to a year ago, how is your family doing financially these days?"; "Do you think that a year from now how will be your family financially". In response to the question "Do you think that this is generally a good or bad time to buy things like furniture, refrigerator, television, two-wheeler, car?" sixty percent of respondents responded as bad time or about the same. Secondly, an overwhelming majority (seventy percent) either strongly disagree or somewhat disagree with "the government's claims about "acchey din" (good days) for the common people?" Finally, when asked "please feel free to provide your opinion about why you support or oppose the present government", two respondents in the lower middle-income category opined as follows: "Decisions taken in haste turned to be disastrous for the present government" and "I don't totally oppose or support the present government as the promises made by them could really better the situations of the country. The reasons to moderately oppose them are that they are very slow to react, till now nothing has changed, rather few things deteriorated". Thus, we find reasonable support for our first proposition P1: The lower-middle income level population who may not have access to physiological needs may exhibit negative attitude towards the government's claims

Fifty nine percent of respondents in the middle-tier noted that they are better off when asked "Compared to a year ago, how is your family doing financially these days?" while fifty percent of respondents noted they will be better off when asked "Do you think that a year from now your family will be financially". When asked "Do you think that this is generally a good or bad time to buy things like furniture, refrigerator, television, two-wheeler, car?" about sixty four percent of respondents noted good time; when asked the question "Do you think that compared to last year, government red tape in everyday affairs this year (decreased, remained the same, increased)", about sixty seven percent of the respondents responded decreased; finally, when asked about whether they agree with the government's claim about "acchey din" (good days), about seventy percent of the respondents opined they either moderately agree or strongly agree. Therefore, the author argues that in general, respondents categorized as belonging to the middle spectrum of the middle-income population generally harbor a positive view of the government, thereby lending credence to our second proposal: P2: Population at the middle-income level who perceive that they have access to better and more resources than before, may have a positive attitude towards the government's claims

We asked the following questions to inquire about improvement in standard of living of the respondents: "Compared to a year ago, how is your family faring financially these days?" and "Do you think that a year from now how your family 
would be faring financially?" Seventy nine percent and seventy percent of respondents noted they were better or same for these two questions respectively.

We also queried our subjects on the following questions, with possible responses as increased, stayed the same, or decreased: "Do you think that compared to last year, the cost of living this year has..."; "Do you think that compared to last year, your healthcare costs this year have..." and "Do you think that compared to last year, education costs this year have...". Sixty five percent, seventy three percent and sixty percent of respondents chose decreased or stayed the same respectively for these two questions. Consequently, the author argues that there is considerable support for the third proposition P3: Population that perceives an improved standard of living compared to the past may exhibit a positive attitude towards the government's claims

Our survey respondent's ability to access more luxury goods was measured by their perceived buying power of higher-end consumer goods and perception about cost of living. To that end, the survey posed the following two questions: "Do you think that this is generally a good or bad time to buy things like furniture, refrigerator, television, two-wheeler, car?" and "Do you think that compared to last year, the cost of living this year has increased, stayed the same or decreased?" Eighty percent of respondents noted good time or same as other times in response to the first question, whereas sixty eight percent of respondents noted decreased or stayed the same. Thus, the author concludes that there is marginal support for the fourth proposition P4: Population that now has access to more luxury goods than before and hence higher self-esteem, may exhibit a positive attitude towards the government's claims.

Historical data suggests that the middle-income population of India (like in many other countries) have enjoyed considerable increase in income over the last decade. This has resulted in access to more goods and services which were hitherto beyond their reach (such as electronic gadgets, automobiles, high-end televisions etc.), resulting in an upliftment in the standard of living and/or quality of life (Kharas 2017). On one hand, both the number and percentage of the population at the poverty or low-middle income level (by World Bank standards) have steadily decreased since 1985 and is predicted to continue to do so until at least 2025. On the other hand, the percentage of the population joining the ranks of "middle-class" have exponentially increased, and the trend is expected to continue till at least 2025 (Ablett et al. 2007).

For most middle-income individuals (income 20,000 rupees per month or less), their perception of improvement in standard of living and eventual support of the government's policies are guided by how far their consumption enhances their "status symbol" in the eyes of their peers. In other words, most citizens in this category assess their own financial and economic well-being not necessarily based on what they have but based on what they do not have, and frequently use their higher-income counterparts as a "benchmark" to assess whether they are better or worse off than before. Consequently, such perception plays a critical role in their assessment of the government's performance.

Historical data, once again, supports the author's contention in this respect. For middle-class consumers, their spending pattern has been steadily shifting from 
basic necessities (food, beverage, apparel) to discretionary items (transportation, communication, education, recreation and healthcare). For example, middle-class consumers spent $51 \%$ on basic necessities and $18 \%$ on discretionary items in 1995. The corresponding numbers for 2005, 2015 and 2025 (predicted) are 48\% and $31 \% ; 39 \%$ and $37 \%$ and $34 \%$ and $48 \%$ respectively (Ablett et al. 2007).

In order to investigate the respondents' perception of their improvement in standard of living, the survey posed the following four questions: 1) "Compared to a year ago, how is your family faring financially these days? (Better, Same, Worse)" 2) "Do you think that compared to last year, your healthcare costs this year have (increased, stayed the same, decreased)" 3) "Do you think that compared to last year, education costs this year have (increased, stayed the same, decreased)"; and 4) "Referring to the government's claims about "acchey din" (good days), do you (Strongly Disagree, Moderately disagree, Neither Agree nor Disagree, Moderately agree, Strongly Agree) with that claim?" As per the results of the survey, for question 1, sixty five percent of respondents noted same or worse off; for question 2, seventy one percent noted increased or stayed the same; for question 3, seventy five percent noted increased or stayed the same; and for question 4, eighty percent noted strongly disagree or moderately disagree. Based on these numbers, therefore, the author argues that low-middle income individuals felt that their social and economic position had become worse off than before, their cost of living had increased and finally, they strongly disagreed with the government's claim that good days had arrived during the current government's rule. The author, therefore, claims that there is moderate to strong support for his fifth proposition P5: Population at the low-middle income level may be worse off compared to high-middle income people, and hence, may exhibit a negative attitude towards the government's claims.

Conversely, upper-middle income citizens of India perceive their fortunes soar because of considerable increase in income, availability of higher-end consumer goods and services, which not only leads to higher perceived standard of living but also positions them at a higher social status compared to their lowerincome counterparts. As such, the upper-middle income citizens of India may have a positive attitude towards the government claims of "good days" and improvement in general conditions of the common people. Referring to the same four questions in the preceding section, the upper-middle income category responded as follows: for question 1, fifty-two percent noted better off or same; for question 2, forty nine percent noted decreased or stayed the same; for question 3, sixty percent noted decreased or stayed the same, while for question 4, forty three percent noted strongly agree or moderately agree. Therefore, the author failed to find moderate support for his sixth and final proposition: P6: Population at the top of the economic ladder may exhibit a positive attitude towards the government's claims. 


\section{Summary, Implications, Limitations, and Future Directions}

The goal of this pilot study was to assess the Indian government's recent claims that its globalization policies have had a positive effect on the economy and the quality of life of its people. For this purpose, the author collected primary data from Indian citizens through an online survey, as well as secondary data from the Indian government and international economic development organizations (World Bank, Government of India, Asian Development Bank).

After the data was compiled, subjects' responses (product purchase behavior, health care, education opportunities, living standards and trust in the present government) were measured using categorical scales, ordinal scales and fixedanchor scales. Given that this was a pilot study, the author collected data from a small sample of about 30 respondents. As such, no sophisticated statistical analysis was conducted, nor was that the author's intention in the first place. Instead, the author ran cross tabs of the responses across different income categories and assessed the respective responses to draw a conclusion for each of his six propositions. The author found moderate to strong support for five propositions, while he failed to find any support for one of his propositions.

This pilot study has several implications from a global marketing perspective. Today, India is considered as one of the most "happening" countries in the world. Frequently referred to in the context of the BRICS conglomerate (Brazil, Russia, India, China, South Africa), India has exhibited highest levels of growth over the last several years. It has made its mark not just economically but also in terms of space exploration, knowledge management, education, foreign collaboration and infrastructure development etc. Many of the economically strongest countries including Japan, US, China, France, UK and Germany have strategic and trade partnerships with India that are critical from both regional stability as well as global development perspectives.

Kharas (2017) notes that the world's middle-class could potentially spend almost $\$ 10$ trillion more by 2022 than what they spend today (purchasing power parity, constant 2011 dollars) of which, Indian middle-class alone could be spending almost 2.4 trillion dollars. Looking at specific spending trends, the Indian middle-class spent about 1.9 trillion dollars $(5 \%$ of the top 10 middle-class spenders) in 2015. The corresponding numbers for 2020 and 2030 are projected at $\$ 3.7$ trillion (9\%) and \$10.7 trillion (17\%). In other words, the Indian middle class has exhibited phenomenal growth and the trend is expected to continue well into the next decade. Given that the middle-class is the most predominant earner in India (as in many other countries), it is no surprise that India has demonstrated the highest growth rate of all countries in the world for a considerable portion of the last decade.

The current research is representative of some of the conflicting indicators of government's performance between developed and developing countries (that may otherwise be masked by international indicators of progress). For example, it is hard to explain why $70 \%$ Indians have greater confidence in their own government (which has been historically perceived as slow, inefficient, and corrupt) than that by Americans, where confidence level has dropped a whopping 37\%? (McCarthy 
2018). Why did the latest economic downturn affect the industrialized countries more severely than countries like India (as exemplified by India's current growth rate of $7.1 \%$ vs US growth rate of $1.6 \%$ )? The author hopes to find answers to such perplexing questions by conducting a detailed analysis of the government's claims on one hand, and views of the middle-class person in India on the other. Insights such as these can help the government reshape their policies and priorities so that the country can harness the full benefits of the government's efforts towards development.

From a marketing practitioner's perspective, the relation between the government and the citizens of the country is similar to that between a "serviceprovider" and the "customer". The government's responsibility is to provide service to the citizen (i.e., the "customer") in lieu of the taxes he/she pays to the government. Very often, however, the customer rates the quality of service as "low", mainly because of one or both of the following reasons: a) quality of service is a "perception" that is highly subjective and 2) differences in perception of what the provider feels is "good service" and what the customer expects as "good service" (Dabholkar 2015, Bansal and Taylor 2015, Kaura et al. 2015). For example, the government might feel that a period of 3 months is appropriate to issue a driver's license or a passport, but the private citizen might feel that it is too long. Consequently, the researcher feels that an in-depth research based on comparative study of candid feedback from the government personnel and the common man has larger implications in terms of marketing, ethics, customer service, customer relationship management and policy.

The current pilot study lays the perfect groundwork for a more detailed, fullblown study in the near future for which, the author has already designed a more rigorous instrument. Given that five out the six propositions received moderate to strong support, the author is encouraged to conduct a more extensive study that will involve collecting data from at least 300 respondents. The author will conduct exploratory factor analysis once the data is collected and coded and will perform a multiple regression of the dependent variables on the independent variable. The respondents' perceptions about purchase behavior, prices, health care, education opportunities, living standards and trust in present government constitute the independent variables, whereas the perception/attitude towards the present Indian government's claims (about the effects of its policies) is the dependent variable for the future research model.

The current research has several indirect implications as well: 1. The present Indian government has done a superb job of marketing the country's interests, aspirations and vision to the global community. It is because of such efforts that India's indicators of progress have been acknowledged and lauded not just as an Asian superpower but also by the entire international community. 2. The efficiency and effectiveness of some of the draconian measures (demonetization, "aadhar" scheme, goods and services tax, to name a few) are in question, and have not yielded the desired results. Consequently, it is important to gauge the effect of the present government's globalization efforts through the eyes of the common person. 3. Surprisingly, a quick search using relevant keywords revealed no research on the ABI-inform database. Thus, given the importance of India from a 
global perspective, the current research addresses a major gap. 4. The data collected from this research can be applied to conduct a comparative study between India and the US civil system (for example, why is the average American citizen more "law-abiding" compared to the average Indian citizen; why was the US banking system affected much more adversely by the recent economic downturn compared to the Indian banking system?) 5. The author can also conduct a similar survey on Indians residing abroad and apply a test for difference of means methodology. It will reveal if resident Indians perceive their government significantly different from non-resident Indians (aka NRI-s). In other words, the author believes that this research project can and will motivate a renewed interest in the globalization efforts by the current Indian government.

One obvious limitation of this research is the recency of the data posted on government and other organizational websites. Realizing that this issue is beyond his control, the researcher will make every attempt to interview government representatives and collect primary data. Another limitation is to come up with a universally-acceptable portfolio of items representing all dimensions of "global marketing". Consequently, the author has focused on the following five dimensions of globalization: product purchase behavior, health care, education opportunities, living standards and trust in the present government.

A second limitation is the small sample size of thirty, which is acceptable for a qualitative pilot study of this nature (Johanson and Brooks 2010, Hertzog 2008, Birkett and Day 1994). Consequently, the author's goal is to collect data from a much larger sample size of 200-300 for his final research study, which is already under way. The author believes the results of this pilot study will be a great asset in honing the quality, validity, reliability -and hence, the generalizability of the final study.

\section{References}

Ablett J, Baijal A, Beinhocker E, Bose A, Farrell D, Gersch U et al. (2007). The 'bird of gold': the rise of India's consumer market. McKinsey Global Institute, 79.

Ahmad I, Reifeld H (2017) The social character of the Indian middle class. In MiddleClass Values in India and Western Europe, 85-97. Routledge.

Ajzen I (1985) From intentions to actions: a theory of planned behavior. In Action Control, 11-39. Berlin, Heidelberg: Springer.

AlEnezi A, AlMeraj Z, Manuel P (2018) Challenges of IoT based smart-government development. In Green Technologies Conference (GreenTech), 2018, 155-160. IEEE.

Amadeo K (2019) US economic outlook for 2018 and beyond. US Economy.

American Marketing Association (2018) Definitions of marketing. Retrieved from: https://www.ama.org/the-definition-of-marketing-what-is-marketing/. [Accessed 20 June 2018]

Anderson PM, He X (2015) Consumer behavior in East/West cultures: implications for marketing a consumer durable. In Proceedings of the 1996 Multicultural Marketing Conference, 3-8. Springer, Cham. 
Asongu S (2014) Globalization (fighting), corruption and development: how are these phenomena linearly and nonlinearly related in wealth effects? Journal of Economic Studies 41(3): 346-369.

Banerjee R, Roy SS (2014) Human capital, technological progress and trade: what explains India's long run growth? Journal of Asian Economics 30(Feb): 15-31.

Bansal HS, Taylor S (2015) Investigating the relationship between service quality, satisfaction and switching intentions. In Proceedings of the 1997 Academy of Marketing Science (AMS) Annual Conference, 304-313. Springer, Cham.

Bartsch F, Riefler P, Diamantopoulos A (2016) A taxonomy and review of positive consumer dispositions toward foreign countries and globalization. Journal of International Marketing 24(1): 82-110.

Basak N (2017) Impacts of progressive tax reform in India: goods and services tax (Gst) An approach. Journal of Commerce \& Accounting Research 6(4): 36-43.

Basu R (2016) Public service guarantee acts in Indian states: tools of accountability and ethical governance. In Governance in South Asia, 73-91. Routledge India.

Beckett C, Taylor H (2016) Human growth and development. Sage.

Bernstein A (2014) The democratic alternative from the South India, Brazil, and South Africa. Democracy Works.

Bhattacharya M, Paramati SR, Ozturk I, Bhattacharya S (2016) The effect of renewable energy consumption on economic growth: evidence from top 38 countries. Applied Energy 162(Jan): 733-741.

Birkett MA, Day SJ (1994) Internal pilot studies for estimating sample size. Statistics in Medicine 13(23-24): 2455-2463.

Birdsall N (2010) The (indispensable) middle class: or, why it's the rich and the rest, not the poor and the rest. Working Paper 207. Washington, DC: Center for Global Development.

Birkett MA, Day SJ (1994) Internal pilot studies for estimating sample size. Statistics in Medicine 13(23-24): 2455-2463.

Blair H (2018) Citizen participation and political accountability for public service delivery in India: remapping the World Bank's routes. Journal of South Asian Development 13(1): 54-81.

Broner F, Ventura J (2016) Rethinking the effects of financial globalization. The Quarterly Journal of Economics 131(3): 1497-1542.

Burgess S (2015) The US Pivot to Asia and Renewal of the US-India Strategic Partnership. Comparative Strategy 34(4): 367-379.

Chakrabarti A, Dhar AK, Dasgupta B (2015) The Indian economy in transition: globalization, capitalism and development. Cambridge University Press.

Chanda A (2016) Notes (and anecdotes) on demonetization in India. Baton Rouge: Louisiana State University.

Chaudhuri B, König L (2017) The Aadhaar scheme: a cornerstone of a new citizenship regime in India? Contemporary South Asia 26(2): 127-142.

Coale AJ, Hoover EM (2015) Population growth and economic development. Princeton University Press.

Dabholkar PA (2015) How to improve perceived service quality by increasing customer participation. In Proceedings of the 1990 Academy of Marketing Science (AMS) Annual Conference, 483-487. Springer, Cham.

Dabla-Norris ME, Kochhar MK, Suphaphiphat MN, Ricka MF, Tsounta E (2015) Causes and consequences of income inequality: a global perspective. International Monetary Fund.

Datta Y (2014) Maslow's hierarchy of basic needs: an ecological view. Oxford Journal: An International Journal of Business \& Economics 8(1). 
De Neve E, Powdthavee N (2016) As the richest get richer, everyone else gets less happy. LSE Business Review.

Donner H (2016) Domestic goddesses: maternity, globalization and middle-class identity in contemporary India. Routledge.

Envall HDP, Hall I (2016) Asian strategic partnerships: new practices and regional security governance. Asian Politics \& Policy 8(1): 87-105.

Fishbein M, Jaccard JJ (1973) Theoretical and methodological considerations in the prediction of family planning intentions and behavior. Representative Research in Social Psychology 4(1): 37-51.

Fishbein M, Ajzen I (1975) Belief. Attitude, intention and behavior: an introduction to theory and research. Reading, MA: Addison-Wesley

Fishbein M, Jaccard J, Davidson AR, Ajzen I, Loken B (1980) Predicting and understanding family planning behaviors. In I Ajzen, M Fishbein (eds.), Understanding Attitudes and Predicting Social Behavior. Prentice Hall.

Galanter M (2015) Competing equalities: law and the backward classes in India. Review Projector (India) 4(5-6). New Delhi: Oxford University Press.

Ganguli BN (2016) Some aspects of classical political economy in the nineteenth century Indian perspective. Orient Longman (1979).

Gunnars K (2018) How many calories should you eat per day to lose weight? Healthline.

Hertzog MA (2008) Considerations in determining sample size for pilot studies. Research in Nursing \& Health 31(2): 180-191.

Javalgi RRG, Grossman DA (2016) Aspirations and entrepreneurial motivations of middle-class consumers in emerging markets: the case of India. International Business Review 25(3): 657-667.

Johanson GA, Brooks GP (2010) Initial scale development: sample size for pilot studies. Educational and Psychological Measurement 70(3): 394-400.

Kaura V, Durga Prasad CS, Sharma S (2015) Service quality, service convenience, price and fairness, customer loyalty, and the mediating role of customer satisfaction. International Journal of Bank Marketing 33(4): 404-422.

Kaushal LA, Pathak N (2015) The causal relationship among economic growth, financial development and trade openness in Indian economy. International Journal of Economic Perspectives 9(2): 5-22.

Kavalski E (2016) The EU-India strategic partnership: neither very strategic, nor much of a partnership. Cambridge Review of International Affairs 29(1): 192-208.

Kharas H (2017) The unprecedented expansion of the global middle class: an update. Working Paper 100. Global Economy \& Development at Brookings.

Khurana A, Sharma A (2016) Goods and services tax in India-A positive reform for indirect tax system. International Journal of Advanced Research 4(3): 500-505.

Kilic C (2015) Effects of globalization on economic growth: panel data analysis for developing countries. Petroleum-Gas University of Ploiesti Bulletin, Technical Series 67(1): $1-11$.

Kleinert J (2018) Globalization effects on the distribution of income (No. 2018-07). Graz: Department of Economics, University of Graz.

Kowalski P, Lopez Gonzalez J, Ragoussis A, Ugarte C (2015) Participation of developing countries in global value chains: implications for trade and trade-related policies. OECD Trade Policy Papers, No. 179. Paris: OECD Publishing.

Krishnan S, Hatekar N (2017) Rise of the new middle class in India and its changing structure. Economic and Political Weekly 52(22): 40-48.

Kumar K (2015) Functioning of anti-money laundering legislation in India a critical study. Doctoral Dissertation. The Tamil Nadu Dr Ambedkar Law University. 
Kumar N (2014) Goods and services tax in India: a way forward. Global Journal of Multidisciplinary Studies 3(6): 216-225.

Malhotra NK, Agarwal J, Shainesh G (2018) Does country or culture matter in global marketing? An empirical investigation of service quality and satisfaction model with moderators in three countries. In Emerging Issues in Global Marketing, 61-91. Springer, Cham.

Mali V (2016) Demonetization: a step towards modified India. International Journal of Commerce and Management Research 2(12): 35-36.

Martin IW (2015) Rich people's movements: Grassroots campaigns to untax the one percent. Oxford University Press.

Maslow AH (1943) A theory of human motivation. Psychological Review 50(4): 370.

Maslow AH (1954) Motivation and personality. Harper and Row.

Maslow AH (1987) Motivation and personality. $3^{\text {rd }}$ Edition. New York: Harper Collins Publishers.

Maslow AH (2013) Toward a psychology of being. Simon and Schuster.

McCarthy N (2018) The countries that trust their government most and least. Forbes.

McLeod S (2007) Maslow's hierarchy of needs. Simply Psychology, 1.

Mitra A (2015) Food security and insecurity in India. New Challenges to Food SecurityFrom Climate Change to Fragile States, 279-297.

Mookherjee D (2014) Accountability of local and state governments in India: an overview of recent research. Indian Growth and Development Review 7(1): 12-41.

Mukherji PAJ (2016) The Indian economy: pushing ahead and pulling apart. In India Briefing, 67-102. Routledge.

Nair M (2017) Can Modi make the elephant dance? Bertelsmann Asia Policy Brief.

Naser H (2015) Analyzing the long-run relationship among oil market, nuclear energy consumption, and economic growth: an evidence from emerging economies. Energy 89(Sep): 421-434.

Passas N (2015) Financial intermediaries-Anti-money laundering allies in cash-based societies? U4 Issue.

Post C, Byron K (2015) Women on boards and firm financial performance: a metaanalysis. Academy of Management Journal 58(5): 1546-1571.

Raj R (2017) Goods and services tax in India. Imperial Journal of Interdisciplinary Research (IJIR) 3(4): 500-505.

Rakodi C (2014) Urban livelihoods: a people-centred approach to reducing poverty. Routledge.

Rama M (2018) Growth out of the blue: nightlight and economic activity. Ahmedabad: Indian Institute of Management Ahmedabad.

Reserve Bank of India (2019) Consumer confidence survey. Retrieved from: https://bit.ly/ 33w8yWS. [Accessed 28 August 2019]

Rose-Ackerman S, Palifka BJ (2016) Corruption and government: causes, consequences, and reform. Cambridge University Press.

Seth A (2016) India-Japan special strategic and global partnership. In India's National Security, 289-298. Routledge India.

Shahbaz M, Mallick H, Mahalik MK, Sadorsky P (2016) The role of globalization on the recent evolution of energy demand in India: implications for sustainable development. Energy Economics 55(Mar): 52-68.

Shahbaz M, Van Hoang TH, Mahalik MK, Roubaud D (2017) Energy consumption, financial development and economic growth in India: new evidence from a nonlinear and asymmetric analysis. Energy Economics 63(Mar): 199-212.

Sharma P (2015) Democracy and transparency in the Indian state: the making of the Right to information act. Routledge. 
Sharma M (2016a) Restart: the last chance for the Indian economy. Random House India.

Sharma D (2016b) Nexus between financial inclusion and economic growth: evidence from the emerging Indian economy. Journal of Financial Economic Policy 8(1): 1336.

Sheth JN, Mittal B, Newman BI (1999) Customer behavior: consumer behavior and beyond. Ft. Worth: The Dryden Press.

Shetty AD (2017) E-commerce industry significant factor for the growth of Indian economy. Asian Journal of Research in Social Sciences and Humanities 7(4): 177183.

Shirley MAJ (2017) Impact of demonetization in India. International Journal of Trend in Research and Development 17(Feb): 20-23.

Singh P, Singh V (2016) Impact of demonetization on Indian economy. In $3^{\text {rd }}$ International Conference on Recent Innovation in Science, Technology, Management and Environment.

Sinha R, Pearson P, Kadekodi G, Gregory M (2017) Income distribution, growth and basic needs in India. Volume 11. Routledge.

Solomon MR, Dahl DW, White K, Zaichkowsky JL, Polegato R (2014) Consumer behavior: buying, having, and being. Volume 10. Pearson.

Soni B, Soni RG (2017) 2016 demonetization in India: missed operational and leadership opportunities. In Competition Forum 15(2): 264-270. American Society for Competitiveness.

Srinivasan J, Bailur S, Schoemaker E, Seshagiri S (2018) Privacy at the margins: the poverty of privacy: understanding privacy trade-offs from identity infrastructure users in India. International Journal of Communication 12: 20.

Suri KC, Elliott C, Hundt D (2016) Democracy, governance and political parties in India: an introduction. Studies in Indian Politics 4(1): 1-7.

Thayer C (2014) India and Vietnam advance their strategic partnership. The Diplomat, 11.

The Economic Times (2018) Indians are having serious second thoughts about Modi's economics. The Economic Times.

The Economic Times (2019) Meter down: At 5\%, GDP growth falls to 6-yr low in June quarter. The Economic Times.

Wilkinson SI (2015) Army and nation: the military and Indian democracy since independence. Harvard University Press.

Wolfers J (2015) Gains from economic recovery still limited to top one percent. New York Times.

World Bank (2012) Economic mobility and the rise of the Latin American middle class. Regional flagship 2012. Washington, DC: Office of the Chief Economist for the Latin America and the Caribbean Region, The World Bank.

Yap B (2017) Anti-corruption high on Indian bank's agenda. International Financial Law Review.

Yeung HWC, Coe N (2015) Toward a dynamic theory of global production networks. Economic Geography 91(1): 29-58. 
